\title{
Zeytin yaprağı ilavesinin zeytinyağının bazı karakteristik özelliklerine etkisi
}

\section{The effect of olive leaf addition on some characteristic properties of olive oil}

\author{
Şerafettin ÇELiK ${ }^{1 *}$ iD, Emine DOĞRU ${ }^{1}$ (D), Yasin YAKAR ${ }^{1}$ iD, Naciye ÜNVER ${ }^{1}$ (iD) \\ ${ }^{1}$ Harran Üniversitesi Mühendislik Fakültesi Gıda Mühendisliği Bölümü Şanlıurfa Türkiye
}

\section{To cite this article:}

Çelik, Ş., Doğru, E., Yakar, Y. \& Ünver, N. (2021). Zeytin yaprağı ilavesinin zeytinyağının bazı karakteristik özelliklerine etkisi. Harran Tarım ve Gıda Bilimleri Dergisi, 25(1): 7285.

DOI: $10.29050 /$ harranziraat.744568

Address for Correspondence: Şerafettin ÇELIK

e-mail:

scelik69@harran.edu.tr

Received Date:

28.05.2020

Accepted Date:

08.12.2020

\section{öz}

Bu çalışmada, zeytin yaprağı ilavesinin Ayvalık çeşidi zeytinden üretilen zeytinyağının bazı karakteristik özelliklerine etkisinin tespit edilmesi amaçlanmıştır. Bu amaçla, oda sıcaklığında 12 ay süre depolanan zeytinyağlarının serbest asitlik, peroksit değeri, toplam fenolik madde, antioksidan kapasite, indüksiyon süresi, özgül absorbans, renk ve yağ asitleri kompozisyonu incelenmiştir. Yapılan istatistiksel değerlendirmede kontrol grubu yağa oranla, yaprak ilavesiyle üretilen zeytinyağının ortalama serbest asitlik, peroksit değeri, $L^{*}, a^{*}$ ve $b^{*}$ değerleri ile stearik asit, SFA (doymuş yağ asitleri) ve MUFA (tekli doymamış yağ asitleri) oranlarında önemli düzeyde azalma, fenolik madde içeriği, antioksidan kapasite, indüksiyon süresi ile linoleik asit ve PUFA (çoklu doymamış yağ asitleri) oranlarında önemli düzeyde yükselme tespit edilmiştir. Yapılan değerlendirmeler ışığında, yaprak ilavesiyle üretilen zeytinyağının oda şartlarında en az 12 aylık süre ile oksidatif stabilitesini koruduğu, yaprak ilavesinin yağın oksidasyon stabilitesine olumlu katkı sağladığı, özellikle \%4 (g/g) yaprak ilavesiyle üretilen zeytinyağının daha uzun süreyle oksidatif stabilitesini koruyacağı sonucuna varılmıştır.

Anahtar Kelimeler: Natürel zeytinyağı, Zeytin yaprağı, Peroksit değeri, Oksidatif stabilite, Yağ asitleri bileşimi

\section{ABSTRACT}

In this study, it was aimed to investigate the effect of olive leaf addition on some characteristic properties of virgin olive oil produced from Ayvalık variety. Forth is purpose, olive oils were analyzed for free acidity, peroxide value, total phenolics, antioxidant capacity, induction time, specific absorbance, color and fatty acid composition for 12 months storage at room temperature. As a result of the statistical evaluation, compared to the control group oil, the average free acidity, peroxide value, $L * a *$ and $b *$ values and stearic acid, SFA and MUFA ratios of olive oils produced with the addition of leaves were significantly decreased; while a significant increase in the content of phenolic substance, antioxidant capacity, induction time, linoleic acid and PUFA ratios were determined. It was concluded that olive oil produced with the addition of leaves preserves its oxidative stability in the room conditions for at least 12 months, the addition of leaves positively contributes to the oxidative stability of the olive oil, and especially the olive oil produced with the addition of $4 \%(w / w)$ leaves will maintain the oxidative stability for a longer period of time.

Key Words: Olive oil, Olive leaf, Peroxide value, Storage stability, Fatty acid composition

\section{Giriş}

Zeytinyağı, fiziksel ve mekanik işlemler sonucu zeytin ağacı (Olea europea L.) meyvesinden elde edilen, yeşilden sarıya doğru değişen renkte kendine özgü tat-koku ve aroması olan ve rafine edilmeden tüketilebilen bir yağdır (Anonim, 2017; Sakar ve Ünver, 2014). Zeytinyağı bileşiminde tekli 
doymamış yağ asitleri dışında, düşük düzeyde bulunan ve yağın oksidasyon stabilitesi üzerinde olumlu etkisi olan $\alpha$-tokoferol, fenolikler, klorofil ve karotenoidler bulunmaktadır (CarrascoPancorbo ve ark., 2005; Kesen, 2019; ReboredoRodriguez ve ark., 2017; Sahin, Sevgen, \& Samli, 2019; Tarchoune ve ark., 2019).

Yağ ve yağı gıdalar, hidroliz ve oksidasyon reaksiyonları sonucu bozulmakta ve parçalanma ürünleri olan serbest radikaller ürünün raf ömrünü kısaltmaktadır. Bu bağlamda, peroksit zincir reaksiyonlarını engelleme, serbest radikalleri yakalama ve stabilize etme yeteneğine sahip yapay antioksidanlar (BHA, BHT, TBHQ ve propil gallatlar gibi) kullanılmaktadır. Ancak, yapay antioksidanların tüketici sağlığı üzerindeki olumsuz etkileri nedeniyle (Rahila ve ark., 2018), aromatik bitki ekstraktlarının doğal antioksidan amacıyla kullanımına ilgi giderek artmakta, zeytin yaprağı veya ekstraktlarının bu amaç doğrultusunda kullanımı ile ilgili çalışmalar giderek yoğunluk kazanmaktadır (Kiritsakis ve ark., 2017; Sonda ve ark., 2014; Tarchoune ve ark., 2019; Türkoğlu ve Kanık, 2014).

Zeytin yaprağının yüksek biyolojik aktiviteye sahip olduğu, fenolik madde içeriği ile antioksidan kapasitesinin yüksek olduğu zeytin yaprağı ve ekstraktının içerdiği hidroksitirozol, kuersetin ve özellikle oleuropein bileşiklerinin yemeklik yağların oksidatif stabilitesini arttırdığı bildirilmiştir (Harp, 2011; Kiritsakis ve ark., 2017; Sevim, 2011; Sonda ve ark., 2014; Tarchoune ve ark., 2019). Yapılan çalışmalarda Gemlik, Domat, Adana topağı, Adana yerli (Harp, 2011) ve Şanlıurfa ilinde yetiştirilen Halhalı (Ünver, 2018) zeytin çeşitlerine ait zeytin yaprağı ekstraktlarının (100 ve 200 ppm) DPPH radikal tutma kapasitesinin ticari zeytin yaprağı ekstraktı ile benzerlik gösterdiği, BHT'den yüksek ve BHA ile benzer veya daha etkili olduğu bildirilmiştir. Bu nedenle yağların raf ömrünü uzatmak amacıyla doğal bir katkı maddesi olarak zeytin yaprağı ekstraktının kullanılabileceği ifade edilmiştir.

Akdeniz diyetinin temel yağ kaynağı olan zeytinyağı, antihipertansiyon, antiviral, antiinflamator, hipoglisemik, nüroprotektif ve antikanser gibi tüketici sağlığı üzerine olumlu etkilerinin olduğu, yüksek düzeyde içerdiği tekli doymamış yağ asitleri ile biyoaktif fitokimyasallar (fenolik bileşikler, tokoferoller, karotenoidler ve fosfolipitler gibi) ile ilişkili olduğu düşünülmektedir. Bu bağlamda, zeytin ve zeytin yapraklarının Akdeniz ülkelerinde yıllardan beri halk tıbbında yaygın bir şekilde kullanıldığı bilinmektedir. Bu nedenle, Dünya zeytinyağı tüketimi ve zeytin yaprağına olan ilgi giderek artmaktadır (Barbaro ve ark., 2014; ReboredoRodriguez ve ark., 2017; Talhaoui ve ark., 2018; Tarchoune ve ark., 2019).

Gereğinden fazla olgunlaşan zeytin meyvesinde oleuropein miktarının azalmasına bağlı olarak son üründe arzu edilmeyen düzeyde tat değişiminin görüldüğü, bu durumu telafi etmek üzere zeytinyağı üretiminde $\% 2-3$ oranında zeytin yaprağının meyvelere karıştırıldığı eskiden beri yapılan bir uygulama olduğu bildirilmektedir (Ranalli ve ark., 2006). Zeytin yapraklarının ucuz, etkili ve alternatif bir antioksidan olması nedeniyle yağ ve yağlı gıda ürünlerinin duyusal ve besinsel niteliklerini korumada rol oynadığı ve gıdaların raf ömrünü artırmak amacıyla kullanılabileceği ifade edilmektedir (Jemai ve ark., 2009; Schieber ve ark., 2001; Ünver, 2018). Yapılan çalışmalarda, zeytin yaprağı ve ekstraktının yağın fenolik madde miktarını yükselttiği, rafine zeytinyağının raf ömrünü uzattığı, potansiyel doğal antioksidan kaynağı olarak yapay antioksidanların ikamesinde kullanılabileceği bildirilmektedir (Bouaziz ve ark., 2008; Bouaziz ve ark., 2008; Kiritsakis ve ark., 2017; Sahin ve ark., 2019). Aynı zamanda, hasat ile birlikte zeytin meyvesinin \%10'u kadar meyve ile toplanan (Ferreira, Barros, Soares, Bastos, \& Pereira, 2007) ve çoğunlukla değerlendirilemeyen yaprakların meyve ile birlikte değerlendirilmesi, çevre temizliğine ve bölge ekonomisine katkı sağlayacağı düşünülmektedir.

$\mathrm{Bu}$ çalışmada, zeytinyağının depolama/oksidasyon stabilitesi başta olmak üzere bazı karakteristik özellikleri üzerine etkisini tespit etmek amacıyla, farklı oranlarda Ayvalık çeşidi zeytin yaprakları kendi meyvesinden elde edilen zeytinyağı üretiminde kullanılmıştır. 
Üretilen zeytinyağları 12 ay süre ile oda sıcaklığında depolanmış ve depolama periyodu boyunca zeytinyağının bazı karakteristik özelliklerinin değişimi incelenmiştir.

\section{Materyal ve Yöntem}

\section{Materyal}

Zeytinyağı üretiminde, Şanlıurfa ili şartlarında tarımı yapılan Ayvalık çeşidi zeytin meyvesi ile aynı çeşit zeytin ağacı yaprağı kullanılmıştır (Kasım 2017 hasat yılı).

\section{Yöntem}

\section{Natürel zeytinyağı üretimi}

Zeytinyağı üretiminde, geç hasat edilen (Aralık ayı) tamamen olgunlaşmıs siyah ve nem oranı azalmış zeytin meyveleri $(500 \mathrm{~kg}$ ) kullanılmıştır. Zeytinyağı üretiminde, santrifüj yöntemi (3 fazlı) kullanılmıştır. Bu işlem için zeytin meyveleri yıkandıktan sonra çekiçli kırıcılarla kırıımış ve malaksöre alınarak yoğurma işlemi $\left(<30 \quad{ }^{\circ} \mathrm{C}\right)$ gerçekleştirilmiştir. $\mathrm{Bu}$ aşamada, zeytin hamurunun en fazla $1 / 3^{\prime}$ ü oranında su $\left(20^{\circ} \mathrm{C}\right)$ ilave edilmiştir. Yağ, zeytin hamuru içinde akıcı hale gelene kadar (yaklaşık 45 dak) yoğurma işlemine devam edilmiştir. Bu işlemden sonra, yağlı hamur dekantöre alınarak karasu ve tortusundan uzaklaştırılmıştır. Daha sonra, yağ fazı seperatöre alınarak ılık su ile yıkanmış ve ince tortular uzaklaştırılarak zeytinyağı elde edilmiştir. Meyve ile birlikte hasat edilen zeytin yaprağı yıkandıktan sonra iki farklı oranda (\%2 ve \%4, g/g), kırma işlemi öncesinde meyve kitlesine ilave edilerek birlikte parçalanması sağlanmıştır. Zeytinyağı üretimi, Harran Üniversitesi Döner sermaye İşletmesi Ebrulim Zeytinyağı İşletmesi'nde yapılmıştır.

Renkli (amber) şişelere $(250 \mathrm{ml}$ ) ambalajlanan zeytinyağı örnekleri, oda sıcaklığında 12 ay süre ile depolanmış ve depolama periyodunun 1.gün, 3.ay, 6.ay, 9.ay ve 12.aylarında aşağıda yer alan analizler yapılmıştır.

\section{Serbest asitlik tayini}

Bu tayin Türk Gıda Kodeksi Zeytinyağı ve Prina Yağı Analiz Metotları Tebliğinde verilen yönteme göre yapılmış, sonuçlar \% oleik asit cinsinden hesaplanmıştır (Anonim, 2014).

\section{Peroksit tayini}

$\mathrm{Bu}$ işlem nişasta indikatörü varlığında yağa doymuş $\mathrm{KI}$ ilave edilmesi ve $0.1 \mathrm{~N} \mathrm{Na}_{2} \mathrm{~S}_{2} \mathrm{O}_{3}$ ile titrasyonu sonucu hesaplanmıştır (Anonim, 2014).

\section{Toplam fenolik madde tayini}

Bunun için $2.5 \mathrm{~g}$ zeytinyağı $5 \mathrm{ml}$ hekzanda çözülmüş, üzerine $5 \mathrm{ml}$ metanol/su $(60: 40 \mathrm{v} / \mathrm{v})$ ilavesi ile 2 dak çalkalandıktan sonra, hekzan ve metanol/su fazları birbirlerinden 3500 rpm 10 dak santrifüjleme ile ayrılmıştır. Metanolik fazdan 0.2 $\mathrm{ml}$ bir tüpe alınarak saf su ile $5 \mathrm{ml}$ ye tamamlanmış, daha sonra $0.5 \mathrm{ml}$ Folin-Ciocalteu çözeltisi ilave edilmiştir. Yaklaşık 3 dak sonra $1 \mathrm{ml}$ sodyum karbonat çözeltisi (\%35, w/v) tüpe ilave edilerek, karışım saf su ile $10 \mathrm{ml}$ 'ye seyreltilmiştir. Çözeltinin absorbansı 2 saat sonra şahit çözeltiye karşı 725 $\mathrm{nm}$ dalga boyunda ölçülmüştür. Standart olarak kafeik asit çözeltisi kullanılmıştır (Hrncirik \& Fritsche, 2004).

\section{Antioksidan kapasite tayini}

Antioksidan kapasite, DPPH'nın (2,2-diphenyl1-picrylhydrazil) nötrleştirilmesi işleminin spektrofotometrik olarak ölçülmesiyle saptanmıştır. Metanolde hazırlanan (100 $\mu \mathrm{M}) 1.9$ ml DPPH çözeltisi, yağ örneğine eklenmesi sonucu elde edilen karışım 15 dak karanlıkta bekletildikten sonra $517 \mathrm{~nm}$ dalga boyunda absorbansı ölçülmüştür (Jiang, Yamaguchi, Takamura, \& Matoba, 2005).

\section{Oksidatif stabilite ölçümü}

Zeytinyağının hızlandırılmış şartlarda oksidatif stabilitesi, Ransimat 743 (Metrohm CH, Switzerland) cihazı kullanılarak tespit edilmiştir. Oksidasyon ölçümü için $3.5 \mathrm{~g}$ yağ örneği cihaza alınmış ve $120{ }^{\circ} \mathrm{C}^{\prime}$ de $20 \mathrm{~L} \mathrm{~h}^{-1}$ hava akış hızında yağda oluşan uçucu bileşikler su içinde biriktirilerek suyun iletkenliği sürekli ölçülmüştür. Iletkenlik eğrisinin büküldüğü nokta için geçen süre, indüksiyon süresi (saat) olarak kaydedilmiştir (Pullen \& Saeed, 2012). 


\section{Renk tayini}

Renk tayini için Hunter Lab Colourflex cihazı kullanılmıştır. Enstrümantal renk değerleri, CIE sisteminde belirtilen $\mathrm{L}^{*}$ (parlaklık), a* (kırmızlıkyeşillik), $b^{*}$ (sarılık-mavilik) terimleri ile ifade edilmiştir.

\section{Özgül absorbans tayini}

Ultraviyole ışığında özgül absorbans tayini ( $A_{232}$ ve $\left.A_{270}\right)$ için yağ örnekleri, izooktan içinde çözdürüldükten sonra, yağın konjuge dien içeriği $270 \mathrm{~nm}\left(\mathrm{~A}_{270}\right)$, konjuge trien içeriği ise $232 \mathrm{~nm}$ $\left(A_{232}\right)$ dalga boyunda Spektrofotometre cihazında okuma yapılmıştır (Anonim, 2014).

\section{Yağ asitleri bileşimi tayini}

Yağ asitleri bileşim analizi için Gaz Kromatografisi (Thermo Trace GC Ultra) kullanılmıştır (Anonim, 2014). İyi bir ayrım için fırın sıcaklık programı uygulanmıştır. $\mathrm{Bu}$ işlem, $90{ }^{\circ} \mathrm{C}^{\prime}$ de 2 dak beklendikten sonra, $90{ }^{\circ} \mathrm{C}$ 'dan $200{ }^{\circ} \mathrm{C}^{\prime}$ ye dakikada $10{ }^{\circ} \mathrm{C}, 200{ }^{\circ} \mathrm{C}$ 'den $230{ }^{\circ} \mathrm{C}^{\prime}$ ye ise dakikada $3{ }^{\circ} \mathrm{C}$ artacak şekilde ulaşılmış ve bu sıcaklıkta 12 dakika beklenilmiştir. Kolon olarak DB-Wax kolon (30.0m x $250 \mathrm{~mm} \times 0.25 \mu \mathrm{m})$, taşıyıc gaz olarak He (25 $\mathrm{ml} /$ dak) kullanılmıştır. FID sıcaklığı $280{ }^{\circ} \mathrm{C}$, enjeksiyon bloğu sıcaklığı $250{ }^{\circ} \mathrm{C}$, enjekte edilecek örnek miktarı $1 \mu \mathrm{L}$ olarak ayarlanmıştır. Tanımlama için, yağ asitleri metil esterleri (37 adet yağ asidi) standardı (Sigma-Aldrich, St Louis, MO, USA) kullanılmıştır.

\section{istatistiksel analizler}

Çalışmadan elde edilen veriler, çift yönlü ANOVA ile değerlendirilmiştir. Analiz sonucu önemli çıkan ortalamalar arasındaki farklılık Tukey çoklu karşılaştırma testi ile test edilmiştir (Yıldız ve Bircan, 1994). İstatistiksel analizler için, MINITAB 17 istatistik paket programı kullanılmıştır. Çalışma 3 tekerrürlü, analizler ise paralel olarak yapılmıştır.

\section{Araştırma Bulguları ve Tartışma}

\section{Kalite ve oksidasyon parametreleri}

Kontrol ve farklı oranlarda zeytin yaprağı ilavesiyle Ayvalık çeşidi zeytinden üretilen zeytinyağının bazı parametrelerine ait ortalama değerler ve oluşan gruplar Çizelge 1'de verilmiştir.

\section{Serbest asitlik}

Kontrol ile $\% 2$ ve $\% 4(\mathrm{w} / \mathrm{w})$ oranlarda zeytin yaprağı ilavesiyle üretilen zeytinyağlarının ortalama serbest asitlik (\%oleik asit) değerleri birbirinden çok önemli düzeyde $(P<0.01)$ farklı bulunmuş ve sırasıyla $1.16 \pm 0.01,1.14 \pm 0.01$ ve $1.11 \pm 0.01$ olarak hesaplanmıştır (Çizelge 1). Bu çalışma kapsamında Ayvalık zeytin meyvesinden üretilen natürel zeytinyağının serbest asitlik değerleri, farklı oranlarda yaprak ilavesi ile Neb Jmel, Oueslati (Tarchoune ve ark., 2019), Ayvalık (Sari \& Ekinci, 2017; Sevim, 2011); Chemlali ve Zalmati (Sonda ve ark., 2014), Cobrançosa (Malheiro, Casal, Teixeira, Bento, \& Pereira, 2013) çeşidi zeytin meyvesinden üretilen natürel zeytinyağında bildirilen ortalama değerlerden daha yüksek bulunmuştur. Bu çalışma ile literatür bildirimleri arasındaki farklılık çeşit, meyvenin olgunluğu ve hasat sonrası meyvenin depolama şartlarından kaynaklanmış olabilir. Özellikle geç hasat edilen meyvelerde lipolitik enzim aktivitesinin artmasına bağlı olarak serbest asitlik yükselmektedir. Zeytinyağının kalitesini belirleyen serbest asitlik, yağın sınıflandırma ve ticari değeri ile ilgili bilgi vermektedir. Bu nedenle, hasattan başlayarak yağın üretilmesine kadar geçen süreçte, serbest asitlik artışına neden olabilecek etkenlerin minimuma indirilmesi büyük önem taşımaktadır (Sari \& Ekinci, 2017; Tarchoune ve ark., 2019).

Ayvalık çeşidinden elde edilen zeytinyağı üretiminde yaprak ilavesi, zeytinyağında serbest asitliğin azalmasına neden olmuştur. Bu bağlamda, $\% 2$ ve $\% 4$ oranında zeytin yaprağı ilave edilerek üretilen zeytinyağı örneklerinin ortalama serbest asitlik değeri, kontrol grubu zeytinyağına oranla, daha düşük bulunmuştur. Benzer şekilde, zeytin yaprağı ilavesinin Oueslati çeşidinden üretilen zeytinyağında serbest asitliği düşürdüğü (Tarchoune ve ark., 2019), zeytin yaprağı ilavesinin Neb Jmel (Tarchoune ve ark., 2019), Ayvalık ve Memecik (Sevim, 2011) çeşidi zeytinden üretilen zeytinyağının serbest asitlik değerine etkisinin istatistiksel olarak önemli olmadığı; ancak yaprak 
ilave oranının artışına paralel olarak Cobrançosa (Malheiro ve ark., 2013), Ayvalık (Sari \& Ekinci, 2017), Chemlali ve Zalmati (Sonda ve ark., 2014) çeşidi zeytinden üretilen zeytinyağında ise serbest asitliğin yükseldiği bildirilmiştir. Araştırıcıların bildirimleri arasındaki bu farklılık, zeytin çeşidi, hasat olgunluğu, üretim prosesi, iklim ve yetiştirme şartlarından kaynaklanmış olabilir.

Çizelge 1. Kontrol ve farklı oranda zeytin yaprağı ilave edilerek Ayvalık çeşidi zeytinden üretilen zeytinyağının bazı parametrelerine ilişkin ortalama değerler ve oluşan gruplar

Table 1. Average values and formed groups related to the investigated parameters of natural olive oil produced from Ayvalık variety olives by adding olive leaves

\begin{tabular}{|c|c|c|c|}
\hline $\begin{array}{l}\text { Parametre } \\
\text { Parameter }\end{array}$ & $\begin{array}{l}\text { Kontrol } \\
\text { Control }\end{array}$ & $\begin{array}{l}\text { \%2 yaprak katkılı } \\
2 \% \text { leaf added }\end{array}$ & $\begin{array}{c}\text { \%4 yaprak katkılı } \\
4 \% \text { leaf added }\end{array}$ \\
\hline \multicolumn{4}{|l|}{$\begin{array}{l}\text { Kalite ve oksidasyon parametreleri } \\
\text { Quality and oxidation parameters }\end{array}$} \\
\hline $\begin{array}{l}\text { Serbest asitlik (\% oleik asit) } \\
\text { Free acidity (oleic acid \%) }\end{array}$ & $1.16 \pm 0.01^{a}$ & $1.14 \pm 0.01^{a}$ & $1.11 \pm 0.01^{b}$ \\
\hline $\begin{array}{l}\text { Peroksit değeri (meq } \mathrm{O}_{2} \mathrm{~kg}_{-} \mathrm{yag}^{-1} \text { ) } \\
\text { Peroxide value (meq } \mathrm{O}_{2} \mathrm{~kg}^{-\mathrm{fat}^{-1}} \text { ) }\end{array}$ & $2.11 \pm 0.02^{a}$ & $1.78 \pm 0.02^{b}$ & $1.69 \pm 0.02^{b}$ \\
\hline $\begin{array}{l}\left.\text { Fenolik madde içeriği (mg CAE kg-yağ }{ }^{-1}\right) \\
\left.\text { Phenolics ( } m g \text { CAE } k g-f^{-1}\right)\end{array}$ & $160.80 \pm 2.17^{c}$ & $188.08 \pm 2.17^{b}$ & $225.87 \pm 2.17^{a}$ \\
\hline $\begin{array}{l}\text { Antioksidan kapasite (\%) } \\
\text { Antioxidation capacity (\%) }\end{array}$ & $47.21 \pm 0.47^{c}$ & $61.25 \pm 0.47^{b}$ & $79.54 \pm 0.47^{a}$ \\
\hline $\begin{array}{l}\text { İndüksiyon süresi (saat) } \\
\text { Induction time (h) }\end{array}$ & $9.11 \pm 0.04^{c}$ & $9.45 \pm 0.04^{b}$ & $12.20 \pm 0.04^{a}$ \\
\hline \multicolumn{4}{|l|}{$\begin{array}{l}\text { Renk parametreleri } \\
\text { Color patameters }\end{array}$} \\
\hline $\mathrm{L}^{*}$ değeri/ $L^{*}$ value & $23.05 \pm 0.08^{a}$ & $22.08 \pm 0.08^{b}$ & $21.70 \pm 0.08^{c}$ \\
\hline$a^{*}$ değeri / $a^{*}$ value & $2.20 \pm 0.03^{a}$ & $1.99 \pm 0.03^{b}$ & $1.49 \pm 0.03^{c}$ \\
\hline $\mathrm{b}^{*}$ değeri / $b^{*}$ value & $9.27 \pm 0.13^{c}$ & $10.26 \pm 0.13^{b}$ & $11.55 \pm 0.13^{a}$ \\
\hline \multicolumn{4}{|l|}{$\begin{array}{l}\text { Özgül absorbans parametreleri } \\
\text { Specific absorbance parameters }\end{array}$} \\
\hline $\mathrm{K}_{232}$ & $2.34 \pm 0.04$ & $2.25 \pm 0.04$ & $2.21 \pm 0.04$ \\
\hline$K_{270}$ & $0.21 \pm 0.01$ & $0.21 \pm 0.01$ & $0.20 \pm 0.01$ \\
\hline$\Delta \mathrm{K}$ & $-0.001 \pm 0.00^{a b}$ & $-0.004 \pm 0.00^{b}$ & $0.002 \pm 0.00^{a}$ \\
\hline \multicolumn{4}{|l|}{$\begin{array}{l}\text { Yağ asitleri bileşimi (\%) } \\
\text { Fatty acid composition (\%) }\end{array}$} \\
\hline $\begin{array}{l}\text { Palmitik asit }\left(\mathrm{C}_{16: 0}\right) \\
\text { Palmitic acid }\left(C_{16: 0}\right)\end{array}$ & $13.67 \pm 0.03$ & $13.54 \pm 0.03$ & $13.61 \pm 0.03$ \\
\hline $\begin{array}{l}\text { Palmitoleic asit }\left(C_{16: 1}\right) \\
\text { Palmitoleik acid }\left(C_{16: 1}\right)\end{array}$ & $0.80 \pm 0.04$ & $0.76 \pm 0.04$ & $0.79 \pm 0.04$ \\
\hline $\begin{array}{l}\text { Stearik asit }\left(C_{18: 0}\right) \\
\text { Stearic acid }\left(C_{18: 0}\right)\end{array}$ & $2.82 \pm 0.01^{a}$ & $2.77 \pm 0.01^{\mathrm{ab}}$ & $2.75 \pm 0.01^{b}$ \\
\hline $\begin{array}{l}\text { Oleik asit }\left(C_{18: 1}\right) \\
\text { Oleic acid }\left(C_{18: 1}\right)\end{array}$ & $68.45 \pm 0.04$ & $68.36 \pm 0.04$ & $68.28 \pm 0.04$ \\
\hline $\begin{array}{l}\text { Linoleik asit }\left(C_{18: 2}\right) \\
\text { Linoleic acid }\left(C_{18: 2}\right)\end{array}$ & $11.83 \pm 0.03^{b}$ & $12.10 \pm 0.03^{a}$ & $12.11 \pm 0.03^{a}$ \\
\hline $\begin{array}{l}\alpha \text {-Linolenik asit }\left(C_{18: 3}\right) \\
\alpha \text {-Linolenic acid }\left(C_{18: 3}\right)\end{array}$ & $0.68 \pm 0.01$ & $0.69 \pm 0.01$ & $0.69 \pm 0.01$ \\
\hline $\begin{array}{l}\text { Araşidik asit }\left(\mathrm{C}_{20: 0}\right) \\
\text { Arachidic acid }\left(C_{20: 0}\right)\end{array}$ & $0.48 \pm 0.01$ & $0.49 \pm 0.01$ & $0.49 \pm 0.01$ \\
\hline$\sum$ SFA & $16.97 \pm 0.02^{\mathrm{a}}$ & $16.79 \pm 0.02^{b}$ & $16.84 \pm 0.02^{b}$ \\
\hline$\sum$ UFA & $81.76 \pm 0.09$ & $81.90 \pm 0.09$ & $81.86 \pm 0.09$ \\
\hline ¿MUFA & $69.25 \pm 0.04^{a}$ & $69.11 \pm 0.04^{\mathrm{ab}}$ & $69.06 \pm 0.04^{b}$ \\
\hline$\sum$ PUFA & $12.51 \pm 0.04^{\mathrm{b}}$ & $12.79 \pm 0.04^{\mathrm{a}}$ & $12.80 \pm 0.04^{\mathrm{a}}$ \\
\hline
\end{tabular}

¿SFA: Toplam doymuş yağ asitleri; $\sum$ UFA: Toplam doymamış yağ asitleri; $\sum$ MUFA: Toplam tekli doymamış yağ asitleri; $\sum$ PUFA: Toplam çoklu doymamış yağ asitleri

¿SFA: Total saturated fatty acids; ¿UFA: Total unsaturated fatty acids; ¿MUFA: Total monounsaturated fatty acids; $\Sigma$ PUFA: Total polyunsaturated fatty acids

Aynı satırda farklı harflerle gösterilen ortalamalar istatistiksel olarak $(\mathrm{P}<0.05)$ birbirinden farklıdır.

The averages shown with different letters on the same row are statistically $(P<0.05)$ different from each other. 


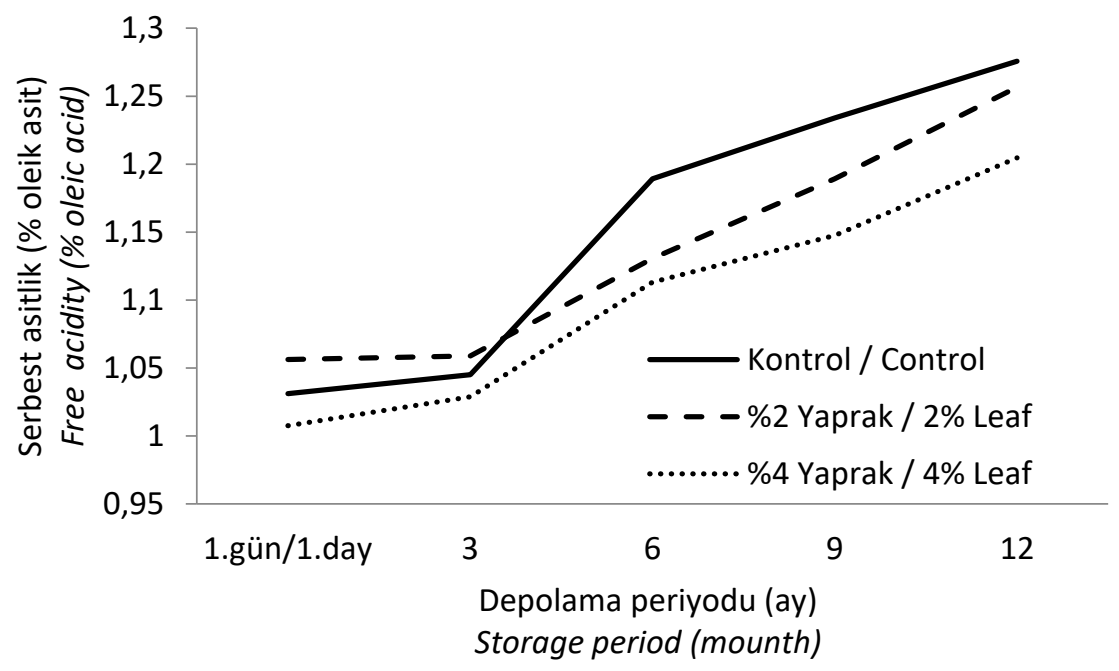

Şekil 1. Kontrol ve farklı oranlarda yaprak ilavesi ile üretilen zeytinyağında serbest asitliğin depolama periyodu boyunca değişimi

Figure 1. The change of free acidity in the control and olive oils produced by adding different amounts of leaves during the storage period

Kontrol ve yaprak katkılı zeytinyağının depolama periyodunun 1. gününde serbest asitlik değerlerinin>\%1 (oleik asit) olması zeytin meyvesinin geç hasat edilmesinden kaynaklandığı düşünülmektedir. Bununla birlikte, kontrol ve yaprak katkılı zeytinyağının depolama periyodunun 12.ayında dahi natürel birinci sınıf zeytinyağı sınıfında yer aldığı tespit edilmiştir (Anonim, 2017). Zeytinyağının serbest asitlik değeri, depolama periyodu boyunca çok önemli düzeyde $(P<0.01)$ artmış, kontrol grubu yağda daha yüksek, yaprak oranının artışına paralel olarak yağda serbest asitlik değeri daha düşük düzeyde seyir izlemiştir (Şekil 1). Depolama periyodu boyunca serbest asitlik değerinin yükselmesi Sevim (2011) tarafından da bildirilmiştir.

\section{Peroksit değeri}

Yapılan bu çalışmada, kontrol ve farklı oranlarda yaprak ilavesiyle üretilen zeytinyağının ortalama peroksit değeri 1.69 $\pm 0.02-2.10 \pm 0.02 \mathrm{meq} \mathrm{O}_{2} \mathrm{~kg}^{-1}$ olarak bulunmuştur (Çizelge 1). Bu çalışmada hesaplanan ortalama peroksit değerleri, farklı oranlarda zeytin yaprak ilavesiyle Tunus Neb Jmel ve Oueslati (Tarchoune ve ark., 2019), Ayvalık (Sahin ve ark., 2019; Sari \& Ekinci, 2017; Sevim ve ark., 2013) ve Cobrançosa (Malheiro ve ark., 2013) çeşidi zeytinden üretilen zeytinyağında bildirilen ortalama değerlerden daha düşük bulunmuştur. Peroksit değeri, oksidasyon sonucu yağda oluşan hidroperoksitlerin doğrudan ölçümüne dayanmaktadır (Malheiro ve ark., 2013; Tarchoune ve ark., 2019). Türk Gıda Kodeksi Zeytinyağı ve Pirina Yağı Tebliği'nde natürel zeytinyağında peroksit değerinin $\leq 20 \mathrm{meq} \mathrm{O}_{2} \mathrm{~kg}^{-1}$ olması gerektiği belirtilmiştir (Anonim, 2017).

Kontrol grubuna oranla, farklı oranda (\%2 ve 4) zeytin yaprağı ilave edilerek üretilen zeytinyağının ortalama peroksit değerleri önemli düzeyde $(P<0.05)$ daha düşük, yaprak oranının artışına paralel olarak zeytinyağının peroksit değerinde de azalma tespit edilmiş, ancak bu durum istatistiksel olarak önemli bulunmamıştır (Çizelge 1). Yaprak ilavesi yapılarak Ayvalık ve Memecik (Sevim, 2011), Cobrançosa (Malheiro ve ark., 2013), Chemlali ve Zalmati (Sonda ve ark., 2014), Ayvalık (\%5 yaprak ilavesi) (Sari \& Ekinci, 2017) çeşidi zeytin meyvelerinden üretilen zeytinyağlarında ortalama peroksit değerlerinin yükseldiği, Tunus Oueslati (Tarchoune ve ark., 2019) çeşidi zeytinyağında peroksit değerinde herhangi bir farklılığın tespit edilemediği, ancak Ayvalık (\%2 zeytin yaprağı) (Sari \& Ekinci, 2017), Neb Jmel (Tarchoune ve ark., 2019) çeşidi zeytinden üretilen zeytinyağında ise peroksit değerinin azaldığı bildirilmiştir. Ayrıca, zeytin yaprağı ekstraktı ilavesinin Ayvalık çeşidinden üretilen zeytinyağı (Sahin ve ark., 2017; Sahin ve ark., 2019) ile rafine zeytinyağında (Bouaziz, Feki, Ayadi, Jemai, \& Sayadi, 2010) peroksit değerinin azalmasına neden olduğu 
bildirilmiştir. Bu durum, zeytinyağının elde edildiği zeytin çeşidi, hasat olgunluğu ve hasat sonrası meyvenin depolama

şartları ve süresinden

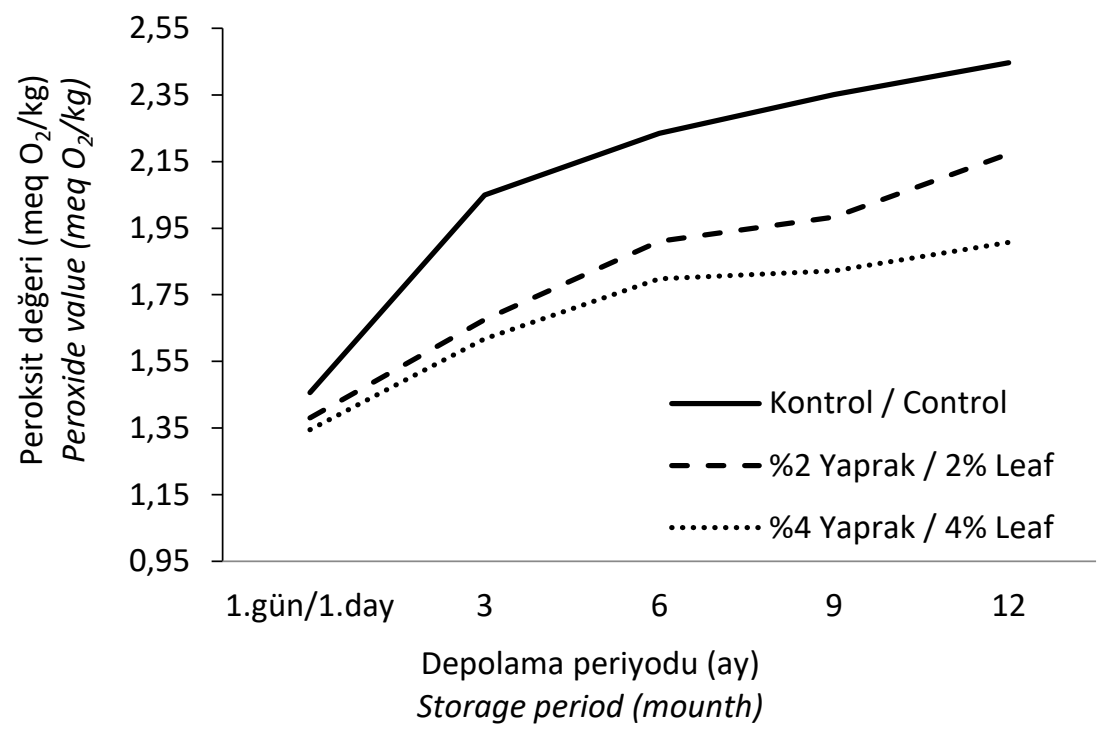

Şekil 2. Kontrol ve farklı oranlarda yaprak ilavesi ile üretilen zeytinyağında peroksit değerinin depolama periyodu boyunca değişimi

Figure 2. The change of peroxide value in the control and olive oils produced by adding different amounts of leaves during the storage period

Depolama periyodu boyunca, yaprak katkılı zeytinyağlarında peroksit değeri, kontrol grubu yağa oranla daha düşük seyretmiş ve depolama periyodu boyunca yağların peroksit değerleri yükselmiştir (Şekil 2). Ayrıca, \%4 yaprak ilavesiyle üretilen zeytinyağında peroksit değeri, \%2 yaprak katkılı zeytinyağına oranla daha düşük bulunmuştur. Depolama periyodu boyunca peroksit değerinin yükselmesi Sevim (2011) tarafından da bildirilmiştir.

\section{Toplam fenolik madde}

Kontrol ve yaprak ilavesiyle üretilen zeytinyağının toplam fenolik madde miktarı $160.80 \pm 2.17-225.87 \pm 2.17 \mathrm{mg} \mathrm{CAE} \mathrm{kg}{ }^{-1}$ arasında tespit edilmiştir (Çizelge 1). Toplam fenolik madde miktarı, Neb Jmel zeytinyağında 736 mg GA eşdeğer/kg yağ, Oueslati yağında ise $528 \mathrm{mg}$ GAE/kg (Tarchoune ve ark., 2019), Chemlali ve Zalmati çeşidi zeytinden elde edilen kontrol ve \%3 yaprak ilavesiyle üretilen zeytinyağında 101.07122.14 ppm ve 343.61-355.00 ppm (Sonda ve ark., 2014); Ayvalık zeytin çeşidine ait kontrol ile \%1 ve \%3 yaprak ilavesiyle üretilen zeytinyağlarında ise 96.06, 124.92 ve $135.23 \mathrm{mg} \mathrm{CAE} / \mathrm{kg}$ yağ (Sevim, 2011) olarak bildirilmiştir. Bu bileşiklerin miktarı, zeytinin cinsi, toprak ve iklim koşulları, olgunlaşma ve depolama şartları gibi faktörlere bağlı olarak değişmektedir (Cavalli ve ark., 2004). Fenolik bileşikler zeytin meyvesinin rengini, besin değerini, zeytinyağının oksidasyonu ve mikrobiyal aktiviteye karşı stabilitesini etkilediği (Cavalli ve ark., 2004), kanser, kardiyovasküler ve nörodejeneratif hastalıkları önlediği (Cinquanta ve ark., 1997) bildirilmektedir.

Kontrol grubuna oranla, yaprak katkılı zeytinyağının toplam fenolik madde içeriği daha yüksek bulunmuş, ayrıca yaprak oranındaki artışa paralel olarak zeytinyağında toplam fenolik madde miktarının da arttığı görülmüştür (Çizelge 1). Benzer şekilde yapılan çalışmalarda yaprak ilavesi yapılarak Ayvalık, (Sahin ve ark., 2017; Sevim, 2011), Memecik (Sevim, 2011), Neb Jmel, Oueslati (Tarchoune ve ark., 2019), Chemlali, Zalmati (Sonda ve ark., 2014) çeşidi meyvelerden üretilen zeytinyağında toplam fenolik madde miktarının artışına neden olduğu bildirilmiştir. Benzer şekilde, farklı düzeyde (187, 261 ve $442 \mathrm{mg} / \mathrm{ml}$ ) zeytin yaprağı ekstraktı ilavesinin rafine zeytinyağı, ayçiçek yağı ve soya yağının fenolik madde içeriğini önemli düzeyde zenginleştirdiği (Japon-Lujan \& De Castro, 2008) bildirilmiştir. 


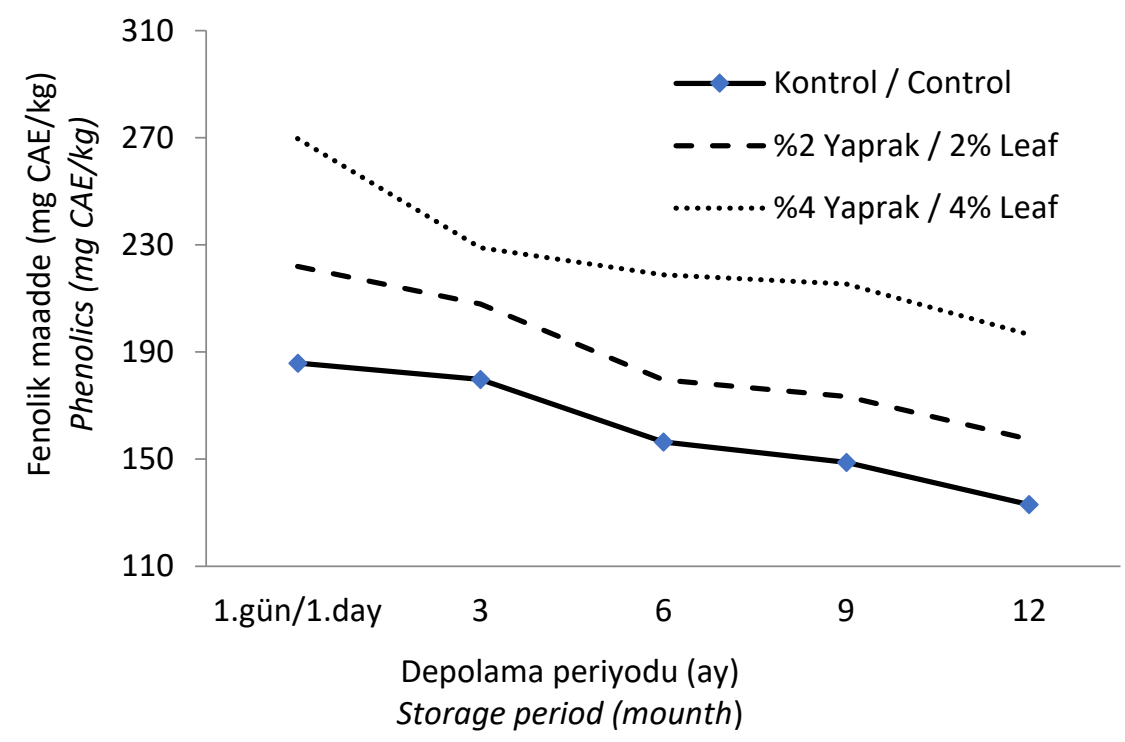

Şekil 3. Kontrol ve farklı oranlarda yaprak ilavesiyle üretilen zeytinyağında toplam fenolik madde miktarının depolama periyodu boyunca değişimi

Figure 3. The change of phenolics in the control and olive oils produced by adding different amounts of leaves during the storage period

Kontrol grubuna oranla, farklı oranda yaprak ilavesiyle Ayvalık çeşidi zeytinden üretilen zeytinyağında toplam fenolik madde miktarı çok önemli düzeyde $(P<0.01)$ daha yüksek bulunmuş ve bu durum depolama periyodu boyunca aynı şekilde devam etmiştir. Ayrıca, natürel zeytinyağlarında fenolik madde miktarı depolama periyodu boyunca azalmıştır (Şekil 3). Benzer değişim Sevim (2011) tarafından Avyalık ve Memecik çeşidi zeytinyağlarının depolama periyodunda da bildirilmiştir.

\section{Antioksidan kapasite}

Antioksidan kapasite (DPPH radikal süpürücü aktivite) kontrol grubu zeytinyağında $\% 47.21 \pm 0.47$, \%2 yaprak ilave edilen grupta $\% 61.25 \pm 0.47$ ve $\% 4$ zeytin yaprağı ilaveli grupta ise $\% 79.54 \pm 0.47$ olarak hesaplanmıştır (Çizelge 1). Antioksidan kapasite (ABTS), yaprak içermeyen Neb Jmel ve Oueslati çeşidi zeytinyağında sırasıyla 69.05 ve $113.84 \mu \mathrm{mol}$ TE/g (Tarchoune ve ark., 2019), Ayvalık çeşidi zeytinden üretilen kontrol ve 1500 ppm yaprak ekstraktı ilave edilen zeytinyağında antioksidan kapasitesinin (ABTS, \%) 13.45 ve 34.09 (Sahin ve ark., 2017); geç hasat edilen (2009 yılı) Ayvalık zeytin çeşidine ait kontrol ile $\% 1$ ve $\% 3$ yaprak ilavesiyle üretilen zeytinyağlarının ortalama antioksidan kapasiteleri
(DPPH) ise $31.90,43.85$ ve $49.75 \mu \mathrm{mol} \mathrm{TE} / 100 \mathrm{~g}$ yağ (Sevim, 2011) olarak bildirilmiştir. Oksidatif bozulma, çoğunlukla depolama sırasında ortaya çıkmakta, yağın kalite ve raf ömrünü olumsuz etkilemektedir (Bouaziz ve ark., 2008; Bouaziz ve ark., 2008).

Kontrol grubuna oranla, yaprak ilave edilerek üretilen zeytinyağında antioksidan kapasitede yükselme görülmüş, bu durum ilave edilen yaprak oranının artışına paralellik arz etmiştir (Çizelge 1). Benzer şekilde, kontrol grubu zeytinyağına oranla farklı oranlarda (\%1 ve 3) kendine ait yaprak ilavesiyle üretilen Ayvalık ve Memecik zeytin çeşitlerine ait zeytinyağının DPPH radikal süpürücü aktivitesinin yükseldiği, en yüksek değerin meyvelere \%3 oranda yaprak ilavesi ile elde edilen yağda tespit edilmiştir (Sevim, 2011). Kontrol grubuna oranla, yaprak ilavesiyle üretilen $\mathrm{Neb}$ Jmel, Oueslati (Tarchoune ve ark., 2019) ve Ayvalık (Sahin ve ark., 2017; Sahin ve ark., 2019) çeşidi zeytinden üretilen zeytinyağında antioksidan aktivitesinin yükseldiği bildirilmiştir. Benzer şekilde, zeytin yaprağı ekstraktı ilavesiyle zenginleştirilen Koroneiki çeşidi zeytinden üretilen zeytinyağında antioksidan aktivitesinin yükseldiği bildirilmiştir (Kiritsakis ve ark., 2017). Bu çalışmada elde edilen değerlerin, literatür bildirimleri ile uyum içinde olduğu söylenebilir. 


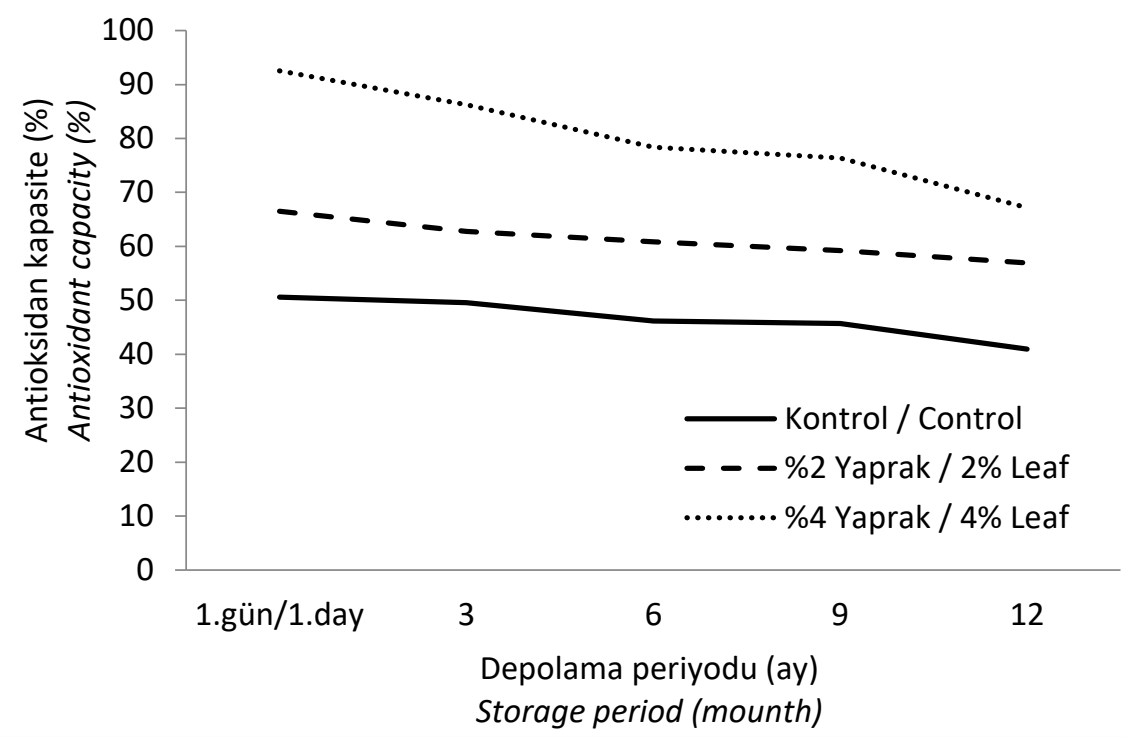

Şekil 4. Kontrol ve farklı oranlarda yaprak ilavesiyle üretilen zeytinyağında antioksidan kapasitenin depolama periyodu boyunca değişimi

Figure 4. The change of antioxidant capacity in the control and olive oils produced by adding different amounts of leaves during the storage period

Zeytinyağının içerdiği toplam fenolik madde miktarına benzer şekilde, kontrol grubu zeytinyağına oranla, yaprak ilavesi içeren zeytinyağının antioksidan kapasitesi çok önemli düzeyde $(\mathrm{P}<0.01)$ daha yüksek bulunmuş ve bu durum depolama periyodu boyunca devam etmiştir (Şekil 4). Ayrıca, \%4 oranında yaprak ilavesi yapılarak üretilen zeytinyağında antioksidan kapasite, \%2 oranında yaprak ilavesi yapılan zeytinyağına oranla, daha yüksek bulunmuştur. Benzer durum, Sevim (2011) tarafından Avyalık ve Memecik çeşidi zeytinyağlarının depolama periyodunda da bildirilmiştir.

\section{Oksidatif stabilite}

Oksidatif stabilite, zamana bağlı olarak yağ örneğinin oksidasyona karşı gösterdiği direnç olarak tanımlanmakta ve ürünün raf ömrü ile ilgili bilgi vermektedir (Coppin \& Pike, 2001; Tan ve ark., 2002). Oksidatif stabilitenin belirlenmesinde çoğunlukla hızlandırılmış oksidasyon yöntemleri kullanılmaktadır. Bu yöntemlerde yağ örneği, sabit hava akışında yüksek sıcaklıkta yağda oluşan uçucu bileşiklerin oranında meydana gelen ani yükselişin belirlenmesiyle tespit edilmekte ve geçen süre indüksiyon süresi olarak tanımlanmaktadır (Sahin ve ark., 2019). Ortalama indüksiyon süresi kontrol grubu zeytinyağında $9.11 \pm 0.04$ saat, \%2 yaprak katkılı grupta $9.45 \pm 0.04$ saat ve $\% 4$ yaprak katkılı grupta ise $12.20 \pm 0.04$ saat olarak ölçülmüştür. Bu çalışmada kontrol ve farklı oranlarda yaprak ilave edilerek üretilen zeytinyağının oksidatif stabilitesi, Ayvalık (Sahin ve ark., 2017; Sahin ve ark., 2019; Sari \& Ekinci, 2017), Chemlali ve Zalmati (Sonda ve ark., 2014), Cobrançosa (2019 yılı) (Malheiro ve ark., 2013) çeşidi zeytinden elde edilen zeytinyağında bildirilen oksidatif stabilite değerlerinden yüksek, 2010 (Ekim ayı) yılında Cobrançosa çeşidi (Malheiro ve ark., 2013) zeytinden üretilen zeytinyağında bildirilen değer ile paralellik göstermektedir. Bu çalışma ile literatür bildirimleri arasındaki farklılık çeşit, meyvenin olgunluğu ve hasat sonrası meyvenin depolama şartlarından kaynaklanmış olabilir.

Kontrol grubu zeytinyağına oranla, yaprak katkılı zeytinyağının oksidatif stabilitesi yükselmiş, yaprak oranının artmasına paralel olarak yağın indüksiyon süresinde de artış tespit edilmiştir. Başka bir ifade ile kontrol grubu yağa oranla, \%2 yaprak ilavesiyle üretilen zeytinyağının oksidatif stabilitesinde \%3.73, \%4 yaprak ilave edilerek üretilen yağın oksidatif stabilitesinde ise \%33.92 düzeyinde artış hesaplanmıştır. Benzer şekilde yapılan çalışmalarda, farklı oranlarda zeytin yaprağı ilave edilmesinin Cobrançosa (Malheiro ve ark., 2013), Ayvalık çeşidi (Sari \& Ekinci, 2017) zeytinden üretilen zeytinyağının oksidatif stabilitesini yükselttiği, ancak Chemlali ve Zalmati 
çeşidi (Sonda ve ark., 2014) zeytin meyvesinden üretilen zeytinyağında oksidatif stabiliteyi düşürdüğü bildirilmiştir. Ayrıca, zeytin yaprağı ilave oranına bağı olarak rafine zeytinyağının oksidatif stabilitesinde 2-7 kat artış görüldüğü ve bu artışın yaprakta bulunan polar phenoller, oleuropein ve $\alpha$ tokoferol içeriğinden kaynaklandığı (Nenadis ve ark., 2010) bildirilmiştir. Ayrıca zeytin yaprağı ekstraktı ilavesinin Ayvalık çeşidi zeytinden üretilen zeytinyağı (Sahin ve ark., 2017; Sahin ve ark., 2019) ile rafine zeytinyağının ransimat değeri ile ölçülen oksidatif stabilitesini yükselttiği ve zeytin yaprağı ekstraktının potansiyel antioksidan kaynağı olarak değerlendirilebileceği (Bouaziz ve ark., 2010; Bouaziz ve ark., 2008) bildirilmiştir. Indüksiyon süresindeki değişim, yağın doymamışlık düzeyi, ilave edilen zeytin yaprağı çeşidi, elde edildiği mevsim ve yağın depolama şartları ve süresinden kaynaklanmış olabilir.

Kontrol grubuna oranla, 12 aylık depolama periyodu boyunca yaprak ilavesi yapılarak üretilen zeytinyağlarında indüksiyon süresi daha yüksek seyretmiştir. Ayrıca, periyot boyunca \%4 yaprak ilavesiyle üretilen zeytinyağında indüksiyon süresi, $\% 2$ yaprak ilavesiyle elde edilen zeytinyağına oranla, daha yüksek bulunmuştur (Şekil 5). Yapılan bir çalışmada, zeytin yaprağı enzimatik hidrolizat ekstraktı ilave edilen rafine zeytinyağının 6 ay depolama sonrası indüksiyon süresinin $0.71 \mathrm{~h}$ olduğu, aynı şartlarda kontrol grubu rafine zeytinyağının indüksiyon süresinin ise $0 \mathrm{~h}$ olduğu bildirilmiştir (Bouaziz ve ark., 2010).

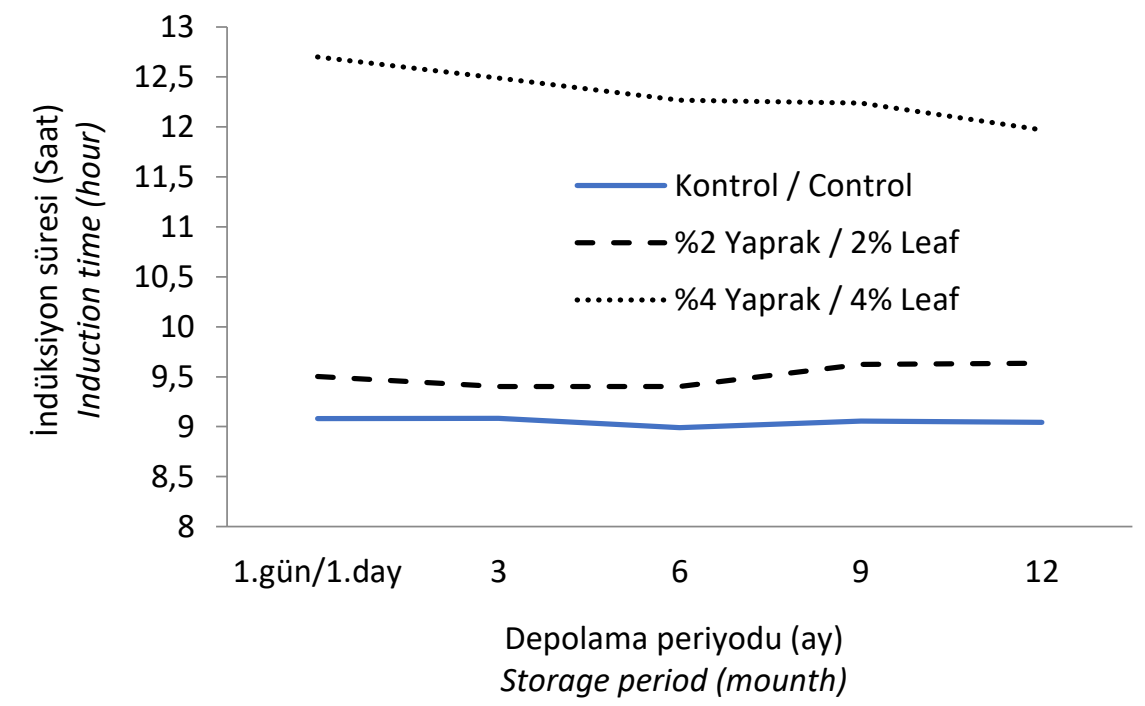

Şekil 5. Kontrol ve farklı oranlarda yaprak ilavesiyle üretilen zeytinyağında oksidatif stabilitesinin depolama periyodu boyunca değişimi

Figure 5. The change of oxidative stability in the control and olive oils produced by adding different amounts of leaves during the storage period

\section{Renk parametreleri}

Bu çalışmada natürel zeytinyağında en yüksek ortalama $L^{*}$ değeri (parlaklık), kontrol grubu zeytinyağında tespit edilmiştir. Yaprak ilavesi ve yaprak oranının artmasına paralel olarak yağda L* değeri azalmıştır. Başka bir ifadeyle yaprak ilavesi zeytinyağında parlaklığın azalmasına neden olmuştur. Zeytinyağı a* değeri bağlamında, gri bölgede yer almaktadır. Kontrol grubu yağa oranla, yaprak ilavesiyle üretilen zeytinyağında a* değeri önemli düzeyde $(P<0.05)$ azalmış ve bu değer \%4 yaprak oranı ilavesiyle üretilen zeytinyağında en düşük değerini almıştır. Yaprak ilavesi zeytinyağında kırmızı renk tonunun azalmasına, yeşil renk tonunun artmasına neden olmuştur. Zeytinyağında en yüksek ortalama $b^{*}$ değeri ise $\% 4$ yaprak ilave edilerek üretilen zeytinyağında tespit edilmiş, yaprak ilavesi zeytinyağında $b^{*}$ değerinin önemli düzeyde $(P<0.05)$ yükselmesine neden olmuştur. Başka bir deyişle, yaprak ilavesi zeytinyağında sarı renk yoğunluğunun artmasına neden olmuştur. Yapılan çalışmalarda, zeytin yaprak ekstraktı ilavesinin zeytinyağında parlaklığının azalması ( $L^{*}$ değerinin düşmesi), yeşil (a* değerinin azaldığı) ve sarı renk tonunun artmasına ( $b$ * değerinin yükselmesi) neden olduğu 
(Kiritsakis ve ark., 2017; Nenadis ve ark., 2010) bildirilmiştir. Bu çalışmada elde edilen renk değerleri, literatür bildirimleri ile paralellik arz etmektedir. Ayrıca, yaprak ilavesi sonucu zeytinyağının renk değerlerinde oluşan bu değişimin göz ile fazla algılanamayacağı, dolayısıyla tüketici beğenisini olumsuz etkilemeyeceği kanaatine varılmıştır.

\section{Özgül absorbans parametreleri}

Kontrol ile $\% 2$ ve $\% 4$ yaprak ilave edilerek üretilen zeytinyağının $\mathrm{K}_{232}$ değerleri arasında önemli bir farklılık bulunmamış ve bu değer sırasıyla $2.34 \pm 0.04,2.25 \pm 0.04$ ve $2.21 \pm 0.04$ olarak bulunmuştur. Yapılan çalışmalarda $K_{232}$ değeri, kontrol ile farklı oranlarda yaprak veya yaprak ekstraktı ilave edilerek Ayvalık zeytin meyvesinden üretilen zeytinyağında 1.6-2.0 (Sari \& Ekinci, 2017; Sevim, 2011); Koroneiki çeşidi zeytinden üretilen zeytinyağında 1.70-1.79 (Kiritsakis ve ark., 2017); Cobrançosa çeşidi zeytin meyvesinden üretilen yağda 1.63-2.61 (Malheiro ve ark., 2013) arasında bildirilmiştir.

Bu çalışmada, kontrol ile farklı oranlarda (\%2 ve 4) yaprak ilave edilerek üretilen zeytinyağında $\mathrm{K}_{270}$ değerleri, $\quad 0.21 \pm 0.01-0.20 \pm 0.01 \quad$ arasında bulunmuştur. Yapılan çalışmalarda bu değer, kontrol ve farklı oranlarda zeytin yaprağı veya ekstraktı ilavesiyle elde edilen Ayvalık çeşidi zeytinden üretilen zeytinyağında 0.12-0.17 (Sari \& Ekinci, 2017; Sevim, 2011); Koroneiki çeşidi zeytinden üretilen zeytinyağında 0.12-0.13 (Kiritsakis ve ark., 2017); Cobrançosa çeşidi zeytin meyvesinden üretilen zeytinyağında 0.09-0.18 (Malheiro ve ark., 2013) aralığında bildirilmiştir.

Kontrol grubu yağa oranla, yaprak ilavesiyle Ayvalık çeşidi zeytinden üretilen zeytinyağlarında $K_{232}$ ve $K_{270}$ değerlerinin azaldığı, $\Delta K$ değerinin ise yükseldiği tespit edilmiştir. Yapılan çalışmalarda, farklı oranlarda (\%1-5) zeytin yaprağı ilavesiyle üretilen Dritta çeşidi zeytin meyvelerden elde edilen zeytinyağının $\mathrm{K}_{232}$ değerlerinin azaldığı, $\mathrm{K}_{270}$ değerlerinin ise değişim gösterdiği (DiGiovacchino ve ark., 1996), Cobrançosa çeşidi zeytin meyvesinden üretilen zeytinyağına farklı oranlarda $(\% 1,2.5,5$ ve $10 ; \mathrm{g} / \mathrm{g})$ zeytin yaprağı ilave edilmesinin $\mathrm{K}_{232}$ ve $\mathrm{K}_{270}$ değerlerinde artışa neden olduğu (Malheiro ve ark., 2013); \%2 ve \%5 oranında zeytin yaprağı ilavesiyle üretilen zeytinyağının $K_{232}$ ve $K_{270}$ değerlerini azalttığı (Sari \& Ekinci, 2017), Ayvalık ve Memecik zeytin çeşitlerine farklı oranda (\%1 ve \%3; g/g) kendine ait zeytin yaprağı eklenerek üretilen zeytinyağında $K_{232}$ değerinin, yaprak ilave oranına göre farklılık gösterdiği, \%3 yaprak ilavesiyle üretilen zeytinyağında $K_{270}$ değerinin en yüksek olduğu (Sevim, 2011) bildirilmiştir.

Zeytinyağında $K_{232}$ değeri, önemli bir kalite kriteri olan oksidasyonun birinci basamağını oluşturan hidroperoksitler ve konjuge dienlerin varlığı; $K_{270}$ değeri ise, oksidasyonun ikinci basamağı olan karbonik bileşikler ile konjuge trienlerin varlığı ile ilgili bilgi vermektedir (Anonim, 2014). Natürel zeytinyağında, $K_{232}$ değerinin en yüksek $2.5, K_{270}$ değerinin en yüksek 0.25 ve $\Delta K$ değerinin $\leq 0.01$ olması gerektiği bildirilmiştir (Anonim, 2014). Bu bağlamda, kontrol ve farklı oranlarda zeytin yaprağı ilave edilerek üretilen zeytinyağlarının $K_{232}, K_{270}$ ve $\Delta K$ değerleri anılan tebliğ ile uyumluluk arz etmektedir.

\section{Yağ asitleri bileşimi}

$\mathrm{Bu}$ çalışmada, kontrol ve yaprak ilavesiyle üretilen zeytinyağının yağ asitleri bileşimi \%98.5 oranında tespit edilmiştir. Bu bağlamda, zeytinyağının bileşiminde doymuş yağ asitlerinden palmitik, stearik ve araşidik asitler, doymamış yağ asitlerinden ise palmitoleik, oleik, linoleik ve $\alpha$ linolenik asitler tespit edilmiştir (Çizelge 1).

Kontrol grubuna oranla, yaprak ilave edilerek üretilen zeytinyağında palmitik, palmitoleik ve oleik asit oranları daha düşük, $\alpha$-linolenik, araşidik asit ile UFA oranları ise yüksek bulunmuş, ancak bu durum istatistiksel olarak önemli bulunmamıştır. Diğer taraftan, kontrol grubu yağa oranla, yaprak ilave edilerek üretilen zeytinyağında stearik asit ile SFA, MUFA oranları önemli düzeyde $(\mathrm{P}<0.05)$ daha düşük, linoleik asit ile PUFA oranları ise daha yüksek $(P<0.05)$ bulunmuştur. Ayrıca, ilave yaprak oranının yükselmesi zeytinyağının yağ asidi bileşimi üzerinde istatistiksel olarak etkisi tespit edilmemiştir. Sonda ve ark. (2014) zeytin yaprağı 
ilavesi ile Chemlali ve Zalmati çeşidi zeytinden üretilen zeytinyağında yağ asitleri bileşiminin değişmediğini, Malheiro ve ark. (2013) 2010 yılında \%10 yaprak ilavesiyle üretilen zeytinyağında oleik asit oranında önemli düzeyde bir azalma, palmitik ve linoleik asit oranlarında ise yükselme tespit edildiğini, 2009 ve 2010 yıllarında ise SFA ve PUFA oranlarında yükselme, MUFA oranında ise önemli düzeyde azalma görüldüğünü; Sevim (2011) ise yaprak ilavesiyle üretilen zeytinyağında stearik ve linoleik asit oranlarının yükseldiğini bildirmiştir. Farklı oranlarda yaprak ilavesiyle elde edilen zeytinyağlarında yağ asitleri bileşiminin farklılık göstermesi zeytin çeşidi, zeytinyağı üretim yöntemi, zeytin meyvelerinin olgunluk durumu, hasat sonrası meyvenin bekletilme süre ve sıcaklığı, kullanılan yaprağın ait olduğu mevsim ve kullanım oranından kaynaklanmış olabilir (Gimeno ve ark., 2002).

Yapılan bu çalışmada, kontrol grubu ile $\% 2$ ve $\% 4$ zeytin yaprağı ilave edilerek üretilen zeytinyağlarının yağ asitleri bileşimlerinin, Türk Gıda Kodeksi Zeytinyağı ve Pirina Yağı Tebliği ile uygunluk arz ettiği tespit edilmiştir (Anonim, 2017).

\section{Sonuç ve Öneriler}

Zeytin yaprağı ilavesinin Ayvalık çeşidi zeytin meyvesinden üretilen natürel zeytinyağının kalitesi ile depolama/oksidatif stabilitesinde önemli rol oynayan fenolik madde içeriğinde artışa neden olduğu, yaprak katkılı zeytinyağlarının en az 12 ay süre ile oda sıcaklığında amber şişede güvenli bir şekilde depolanabileceği, \%4 (w/w) yaprak ilavesiyle üretilen yağın aynı şartlarda daha uzun süre depolanabileceği, yaprak ilavesiyle üretilen zeytinyağlarının Türk Gıda Kodeksi Zeytinyağı ve Pirina Yağı Tebliği ile uygunluk arz ettiği sonucuna varılmıştır. Bölgede yağ üretiminde kullanılan zeytin meyvesinin geç hasat edilmesinden dolayı, zeytinyağının kalite parametrelerinin (serbest asitlik ve peroksit değerleri) yüksek olduğu ve bu durumdan zeytinyağının oksidasyon parametrelerinin de olumsuz etkilendiği, meyve ile birlikte kendine ait zeytin yaprağının üretim prosesine alınmasının yağın kalitesini olumlu etkileyeceği ve aynı zamanda çevre temizliği ve bölge ekonomisine olumlu katkı sağlayacağı düşünülmektedir.

\section{Ekler}

Bu çalışma, Harran Üniversitesi BAP tarafından desteklenmiş (Proje no: 17120) ve Emine Doğru'nun Yüksek Lisans Tezi'nden üretilmiştir.

Çıkar Çatışması Beyanı: Makale yazarları aralarında herhangi bir çıkar çatışması olmadığını beyan ederler.

Yazar Katkısı: Şerafettin ÇELIK çalışmayı planlayarak denemeleri kurmuş, verileri analiz etmiş, Emine DOĞRU çalışmayı yürütmüş, Yasin YAKAR ve Naciye ÜNVER analizlerin yapılmasına katkı sağlamış, Şerafettin ÇELik ve Emine DOĞRU makaleyi yazmıştır.

\section{Kaynaklar}

Anonim (2014). Türk Gıda Kodeksi Zeytinyağı ve Pirina Yağı Analiz Metotları Tebliği (Tebliğ no: 2014/53).

Anonim (2017). Türk Gıda Kodeksi Zeytinyağı ve Pirina Yağı Tebliği (Tebliğ no: 2017/26).

Barbaro, B., Toietta, G., Maggio, R., Arciello, M., Tarocchi, M., Galli, A., \& Balsano, C. (2014). Effects of the OliveDerived Polyphenol Oleuropein on Human Health. International Journal of Molecular Sciences, 15(10), 18508-18524. doi:10.3390/ijms151018508

Bouaziz, M., Feki, I., Ayadi, M., Jemai, H., \& Sayadi, S. (2010). Stability of refined olive oil and olive-pomace oil added by phenolic compounds from olive leaves. European Journal of Lipid Science and Technology, 112(8), 894-905. doi:10.1002/ejlt.200900166

Bouaziz, M., Feki, I., Jemai, H., Ayadi, M., \& Sayadi, S. (2008). Effect of storage on refined and husk olive oils composition: Stabilization by addition of natural antioxidants from Chemlali olive leaves. Food Chemistry, 108(1), 253-262. doi:10.1016/j.foodchem.2007.10.074

Bouaziz, M., Hammami, H., Bouallagui, Z., Jemai, H., \& Sayadi, S. (2008). Production of antioxidants from olive processing by-products. Electronic Journal of Environmental, Agricultural and Food Chemistry, 7(8), 3231-3236.

Carrasco-Pancorbo, A., Cerretani, L., Bendini, A., SeguraCarretero, A., Del Carlo, M., Gallina-Toschi, T., . . . Fernandez-Gutierrez, N. G. (2005). Evaluation of the antioxidant capacity of individual phenolic compounds in virgin olive oil. Journal of Agricultural 
and Food Chemistry, 53(23), 8918-8925. doi:10.1021/jf0515680

Cavalli, J. F., Fernandez, X., Lizzani-Cuvelier, L., \& Loiseau, A. M. (2004). Characterization of volatile compounds of French and Spanish virgin olive oils by HS-SPME: Identification of quality-freshness markers. Food Chemistry, 88(1), 151-157. doi:10.1016/j.foodchem.2004.04.003

Cinquanta, L., Esti, M., \& La Notte, E. (1997). Evolution of phenolic compounds in virgin olive oil during storage. Journal of the American oil chemists' society, 74(10), 1259-1264.

Coppin, E. A., \& Pike, O. A. (2001). Oil stability index correlated with sensory determination of oxidative stability in light-exposed soybean oil. Journal of the American Oil Chemists Society, 78(1), 13-18. doi:DOI 10.1007/s11746-001-0212-4

DiGiovacchino, L., Angerosa, F., \& DiGiacinto, L. (1996). Effect of mixing leaves with olives on organoleptic quality of oil obtained by centrifugation. Journal of the American Oil Chemists Society, 73(3), 371-374. doi:Doi 10.1007/Bf02523433

Ferreira, I. C. F. R., Barros, L., Soares, M. E., Bastos, M. L., \& Pereira, J. A. (2007). Antioxidant activity and phenolic contents of Olea europaea L. leaves sprayed with different copper formulations. Food Chemistry, 103(1),

188-195. doi:https://doi.org/10.1016/j.foodchem.2006.08.006

Gimeno, E., Castellote, A. I., Lamuela-Raventós, R. M., De la Torre, M. C., \& López-Sabater, M. C. (2002). The effects of harvest and extraction methods on the antioxidant content (phenolics, $\alpha$-tocopherol, and $\beta$ carotene) in virgin olive oil. Food Chemistry, 78(2), 207-211. doi:https://doi.org/10.1016/S03088146(01)00399-5

Harp, F. (2011). Gemlik, Domat, Adana Topağı ve Adana Yerli Zeytin Yapraklarının Antioksidan Etkilerinin Belirlenmesi. (Yüksek lisans tezi), Çukurova Üniversitesi, Adana.

Hrncirik, K., \& Fritsche, S. (2004). Comparability and reliability of different techniquesfor the determination of phenolic compounds invirgin olive oil. Europian Journal of Lipid Science and Technology, 106, 540-549.

Japon-Lujan, R., \& De Castro, M. D. L. (2008). Liquid-liquid extraction for the enrichment of edible oils with phenols from olive leaf extracts. Journal of Agricultural and Food Chemistry, 56(7), 2505-2511. doi:10.1021/jf0728810

Jemai, H., El Feki, A., \& Sayadi, S. (2009). Antidiabetic and Antioxidant Effects of Hydroxytyrosol and Oleuropein from Olive Leaves in Alloxan-Diabetic Rats. Journal of Agricultural and Food Chemistry, 57(19), 8798-8804. doi:10.1021/jf901280r

Jiang, L. Q., Yamaguchi, T., Takamura, H., \& Matoba, T. (2005). Characteristics of Shodo Island olive oils in Japan: Fatty acid composition and antioxidative compounds. Food Science and Technology Research, 11(3), 254-260. doi:Doi 10.3136/Fstr.11.254

Kesen, S. (2019). Using chromatographic methods in detection of olive oil adulteration. Harran Tarım ve Gıda Bilimleri Dergisi, 23(3), 335-344.

Kiritsakis, K., Rodriguez-Perez, C., Gerasopoulos, D., \&
Segura- Carretero, A. (2017). Olive oil enrichment in phenolic compounds during malaxation in the presence of olive leaves or olive mill wastewater extracts. European Journal of Lipid Science and Technology, 119(9). doi:Artn 1600425 10.1002/Ejlt.201600425

Malheiro, R., Casal, S., Teixeira, H., Bento, A., \& Pereira, J. A. (2013). Effect of Olive Leaves Addition during the Extraction Process of Overmature Fruits on Olive Oil Quality. Food and Bioprocess Technology, 6(2), 509521. doi:10.1007/s11947-011-0719-z

Nenadis, N., Moutafidou, A., Gerasopoulos, D., \& Tsimidou, M. Z. (2010). Quality characteristics of olive leaf-olive oil preparations. European Journal of Lipid Science and Technology, 112(12), 1337-1344. doi:10.1002/ejlt.201000332

Pullen, J., \& Saeed, K. (2012). An overview of biodiesel oxidation stability. Renewable \& Sustainable Energy Reviews, 16(8), 5924-5950. doi:10.1016/j.rser.2012.06.024

Rahila, M. P., Nath, B. S., Naik, N. L., Pushpadass, H. A., Manjunatha, M., \& Franklin, M. E. E. (2018). Rosemary (Rosmarinus officinalis Linn.) extract: A source of natural antioxidants for imparting autoxidative and thermal stability to ghee. Journal of Food Processing and Preservation, 42(2), 10. doi:10.1111/jfpp.13443

Ranalli, A., Contento, S., Lucera, L., Di Febo, M., Marchegiani, D., \& Di Fonzo, V. (2006). Factors Affecting the Contents of Iridoid Oleuropein in Olive Leaves (Olea europaea L.). Journal of Agricultural and Food Chemistry, 54(2), 434-440. doi:10.1021/jf051647b

Reboredo-Rodriguez, P., Figueiredo-Gonzalez, M., GonzalezBarreiro, C., Simal-Gandara, J., Salvador, M. D., Cancho-Grande, B., \& Fregapane, G. (2017). State of the Art on Functional Virgin Olive Oils Enriched with Bioactive Compounds and Their Properties. International Journal of Molecular Sciences, 18(3). doi:Artn 668 10.3390/ljms18030668

Sahin, S., Sayim, E., \& Bilgin, M. (2017). Effect of olive leaf extract rich in oleuropein on the quality of virgin olive oil. Journal of Food Science and Technology-Mysore, 54(6), 1721-1728. doi:10.1007/s13197-017-2607-7

Sahin, S., Sevgen, S., \& Samli, R. (2019). Estimation of quality parameters in virgin olive oil treated with olive leaf extract: application of artificial neural networks. Chemical Papers, 73(5), 1189-1197. doi:10.1007/s11696-018-0669-2

Sakar, E., \& Ünver, H. (2014). Türkiye'de zeytin yetiştiriciliğinin durumu ve ülkemizde yapılan bazı seleksiyon ve adaptasyon çalışmaları. Harran Tarım ve Gıda Bilimleri Dergisi, 15(2), 19-25.

Sari, H. A., \& Ekinci, R. (2017). The effect of ultrasound application and addition of leaves in the malaxation of olive oil extraction on the olive oil yield, oxidative stability and organoleptic quality. Food Science and Technology, 37(3), 493-499. doi:10.1590/1678457X.22916

Schieber, A., Stintzing, F. C., \& Carle, R. (2001). By-products of plant food processing as a source of functional compounds - recent developments. Trends in Food Science \& Technology, 12(11), 401-413. doi:Pii S09242244(02)00012-2 Doi 10.1016/S0924-2244(02)000122 
Sevim, D. (2011). Zeytin yaprağı ilave edilerek elde edilen zeytinyağlarının bazı temel kalite kriterleri ve antioksidan aktivitelerinin belirlenmesi. Doktora tezi, Ege ÜniversitesiFen Bilimleri Enstitüsü Bahçe Bitkileri Anabilim Dalı, İzmir., İzmir.

Sevim, D., Köseoğlu, O., Altunoğlu, Y., Ölmez, H. A., \& Büyükgök, E. B. (2013). Erkence zeytin çeşidinden elde edilen yağların (hurmalaşmış ve hurmalaşmamış) karşılaştırılması. Gıda, 38(3), 159-166.

Sonda, A., Akram, Z., Boutheina, G., Guido, F., \& Mohamed, B. (2014). Effect of Addition of Olive Leaves before Fruits Extraction Process to Some Monovarietal Tunisian Extra-Virgin Olive Oils Using Chemometric Analysis. Journal of Agricultural and Food Chemistry, 62(1), 251-263. doi:10.1021/jf404395x

Talhaoui, N., Trabelsi, N., Taamalli, A., Verardo, V., GomezCaravaca, A. M., Fernandez-Gutierrez, A., \& ArraezRoman, D. (2018). Olea europaea as Potential Source of Bioactive Compounds for Diseases Prevention. Studies in Natural Products Chemistry, Vol 57, 57, 389411. doi:10.1016/B978-0-444-64057-4.00012-0
Tan, C. P., Man, Y. B. C., Selamat, J., \& Yusoff, M. S. A. (2002). Comparative studies of oxidative stability of edible oils by differential scanning calorimetry and oxidative stability index methods. Food Chemistry, 76(3), 385389. doi:Pii S0308-8146(01)00272-2 Doi 10.1016/S0308-8146(01)00272-2

Tarchoune, I., Sgherri, C., Eddouzi, J., Zinnai, A., Quartacci, M. F., \& Zarrouk, M. (2019). Olive Leaf Addition Increases Olive Oil Nutraceutical Properties. Molecules, 24(3). doi:Artn 545 10.3390/Molecules24030545

Türkoğlu, H., \& Kanık, Z. (2014). Nizip ve çevresinde satışa sunulan zeytinyağı örneklerinin bazı özellikleri. Harran Tarım ve Gıda Bilimleri Dergisi, 16(3), 1-8.

Ünver, N. (2018). Ultrason destekli ekstraksiyon yöntemi kullanılarak zeytin yaprağı ekstraksiyon işleminin optimize edilmesi. Yüksek Lisans Tezi, Harran Üniversitesi Fen Bilimleri Enstitüsü Gıda Mühendisliği Anabilim Dalı, Şanlıurfa, Şanlıurfa.

Yıldız, N., \& Bircan, H. (1994). Uygulamalı Istatistik. Erzurum: Atatürk Üniversitesi Yayınları No: 704. 